\title{
Environmental and biological effects on the stable oxygen isotope records of corals in the northern Gulf of Aqaba, Red Sea
}

\author{
Saber Al-Rousan ${ }^{1,2, *}$, Salim Al-Moghrabi ${ }^{2}$, Jürgen Pätzold ${ }^{1}$, Gerold Wefer ${ }^{1}$ \\ ${ }^{1}$ Fachbereich Geowissenschaften, Universität Bremen, 28359 Bremen, Germany \\ ${ }^{2}$ Marine Science Station, PO Box 195, Aqaba, Jordan
}

\begin{abstract}
Monthly $\delta^{18} \mathrm{O}$ records of 2 coral colonies (Porites cf. lutea and P. cf. nodifera) from different localities (Aqaba and Eilat) from the northern Gulf of Aqaba, Red Sea, were calibrated with recorded sea surface temperatures (SST) between 1988 and 2000. The results show high correlation coefficients between SST and $\delta^{18} \mathrm{O}$. Seasonal variations of coral $\delta^{18} \mathrm{O}$ in both locations could explain $91 \%$ of the recorded SST. Different $\delta^{18} \mathrm{O} / \mathrm{SST}$ relations from both colonies and from the same colonies were obtained, indicating that $\delta^{18} \mathrm{O}$ from coral skeletons were subject to an extension rate effect. Significant $\delta^{18} \mathrm{O}$ depletions are associated with high extension rates and higher values with low extension rates. The relation between coral skeletal $\delta^{18} \mathrm{O}$ and extension rate is not linear and can be described by a simple exponential model. An inverse relationship extends over extension rates from 1 to $5 \mathrm{~mm} \mathrm{yr}^{-1}$, while for more rapidly growing corals and portions of colonies the relation is constant and the extension rate does not appear to have a significant effect. We recommend that $\delta^{18} \mathrm{O}$ values be obtained from fast-growing corals or from portions in which the isotopic disequilibrium is fairly constant (extension rate $>5 \mathrm{~mm} \mathrm{yr}^{-1}$ ). The results show that interspecific differences in corals may produce a significant $\delta^{18} \mathrm{O}$ profile offset between 2 colonies that is independent of environmental and extension-rate effects. We conclude that the rate of skeletal extension and the species of coral involved have an important influence on coral $\delta^{18} \mathrm{O}$ and must be considered when using $\delta^{18} \mathrm{O}$ records for paleoclimatic reconstructions.
\end{abstract}

KEY WORDS: Stable oxygen isotopes - Coral extension rate $\cdot$ Coral calcification rate Porites spp. Gulf of Aqaba $\cdot$ Red Sea

\section{INTRODUCTION}

Massive-growing corals can be used as environmental recorder because their annual growth bands allow the reconstruction of accurate chronologies (Knutson et al. 1972). Massive hermatypic coral skeletons are excellent monitors of tropical water environments. Corals of this type live in the surface-ocean mixed layer, grow continuously at rates of several $\mathrm{mm}$ to $\mathrm{cm}$ per $y r$, and during growth incorporate isotopic species into their skeleton.

*E-mail: alrousan@uni-bremen.de
The stable oxygen isotopic composition $\left(\delta^{18} \mathrm{O}\right)$ of hermatypic corals has been utilised in numerous reconstructions of past sea surface temperatures (SST) and salinities (e.g. Charles et al. 1997, Gagan et al. 2000). Coral $\delta^{18} \mathrm{O}$ reflects a combination of local SST and the $\delta^{18} \mathrm{O}$ value of ambient seawater (Epstein et al. 1953, Wefer \& Berger 1991). However, changes in coral growth rates may change the absolute isotopic values. Variations in the extension and calcification rates have an impact on the fractionation of stable isotopes and have long been a subject of discussion (Land et al. 1975, Goreau 1977, Weil et al. 1981, Pätzold 1986, McConnaughey 1989, de Villiers et al. 1995, Allison et al. 1996, Leder et al. 1996, Cohen \& Hart 1997). Signif- 
icant skeletal $\delta^{18} \mathrm{O}$ depletion in faster-growing areas of coral skeleton compared to slower-growing areas were reported for the first time by Land et al. (1975). Allison et al. (1996) observed in Porites lutea from Phuket, south Thailand, that the growth rate $/ \delta^{18} \mathrm{O}$ relationship is linear at all extension rates, while McConnaughey (1989) found this relation in Pavona clavus from Galápagos only in parts of corals extending at a rate of less than $5 \mathrm{~mm} \mathrm{yr}^{-1}$. For more rapidly growing parts of the coral, extension rate does not appear to have a significant effect on $\delta^{18} \mathrm{O}$.

Few studies have examined skeletal $\delta^{18} \mathrm{O}$ variations within and among species. From studies on corals from Kaneohe Bay, Hawaii, Grottoli (1999) found that $\delta^{18} \mathrm{O}$ values are constant over variable depths for a given species, and that this parameter exhibits interspecific variability. Species-specific offsets in $\delta^{18} \mathrm{O}$ have also been reported by Weil et al. (1981) and Wellington et al. (1996).

In this study we examined skeletal $\delta^{18} \mathrm{O}$ composition of 2 Porites colonies collected from the northern end of the Gulf of Aqaba: from Aqaba at a depth of $19 \mathrm{~m}$ (Porites cf. lutea) and from Eilat at $15 \mathrm{~m}$ (P. cf. nodifera). To evaluate the effect of extension rate that is independent of in situ temperature, variations in the $\delta^{18} \mathrm{O}$ of seawater and specific-species effects, samples for $\delta^{18} \mathrm{O}$ analysis were taken from each specimen along synchronous growth profiles with different extension rates. Previously published and unpublished coral $\delta^{18} \mathrm{O}$ data from the area are also included in this study for comparison. However, the results from this study can be used to evaluate and correct coral $\delta^{18} \mathrm{O}$ values from modern and fossil corals for extension rate effects.

\section{MATERIALS AND METHODS}

The study area is located at the northern end of the Gulf of Aqaba (Fig. 1), which is the northward extension of the desert-enclosed Red Sea. The maximum depth of the Gulf is $1830 \mathrm{~m}$; its $180 \mathrm{~km}$ long and 5 to $26 \mathrm{~km}$ wide. Oligotrophic conditions prevail in the Gulf waters, and evaporation $\left(350 \mathrm{~cm} \mathrm{yr}^{-1}\right)$ greatly exceeds precipitation $\left(3 \mathrm{~cm} \mathrm{yr}^{-1}\right.$ ) (Reiss \& Hottinger 1984).

A column of a Porites cf. nodifera colony was collected in front of the Interuniversity Institute in Eilat $\left(29^{\circ} 31^{\prime} \mathrm{N}, 34^{\circ} 56^{\prime} \mathrm{E}\right)$ at a depth of $15 \mathrm{~m}$ in April 1996 (El-15), while another column of a P. cf. lutea colony (Aq-19) was collected in front of the Marine Science Station in Aqaba $\left(29^{\circ} 27^{\prime} \mathrm{N}\right.$ and $\left.34^{\circ} 90^{\prime} \mathrm{E}\right)$ at a depth of $19 \mathrm{~m}$ in April 1999. Both coral columns were sectioned along their longitudinal axes to obtain slabs of about $4 \mathrm{~mm}$ thickness. X-radiographs were prepared to reveal annual density bands for determining sampling profiles (Fig. 2). Aragonite sub-samples were collected by low-speed drilling using a dentist drill with a $0.6 \mathrm{~mm}$ diameter bit. Distance between samples was about $1 \mathrm{~mm}$ and the drilling depth was $3 \mathrm{~mm}$. A number of 7 to 12 samples (average 9) $\mathrm{yr}^{-1}$ from both corals were obtained along the maximum growth axis (main profile). In addition, we continuously sampled stable isotopic profiles drilled along lateral corallites from the sides of both colonies that showed low growth rate (Fig. 2).

The isotopic composition of the samples was measured with a Finnigan MAT 251 mass spectrometer at Bremen University. All values are reported in per mil relative to VPDB. The average measurement precision for $\delta^{18} \mathrm{O}$ was $\pm 0.07 \%$.

The chronologies of both corals were constructed by designating the maximum $\delta^{18} \mathrm{O}$ value within each year as mid-March (the coldest month in the year according to recent SST records from Eilat and Aqaba). Linear interpolation of 12 equidistant values for the main profiles ( 6 for the side profiles) $\mathrm{yr}^{-1}$ between these maxima was applied, using AnalySeries 1.1 software package (Paillard et al. 1996). This procedure provided a monthly and bimonthly sampling resolution.

Absolute bulk density was measured by gammadensitometry on a Multi Sensor Core Logger (Geotek) with a $\mathrm{Cs}^{137}$ source and $1 \mathrm{~mm}$ collimator at the Ocean Drilling Core Repository in Bremen. The method is based upon the attenuation of a gamma photon beam,

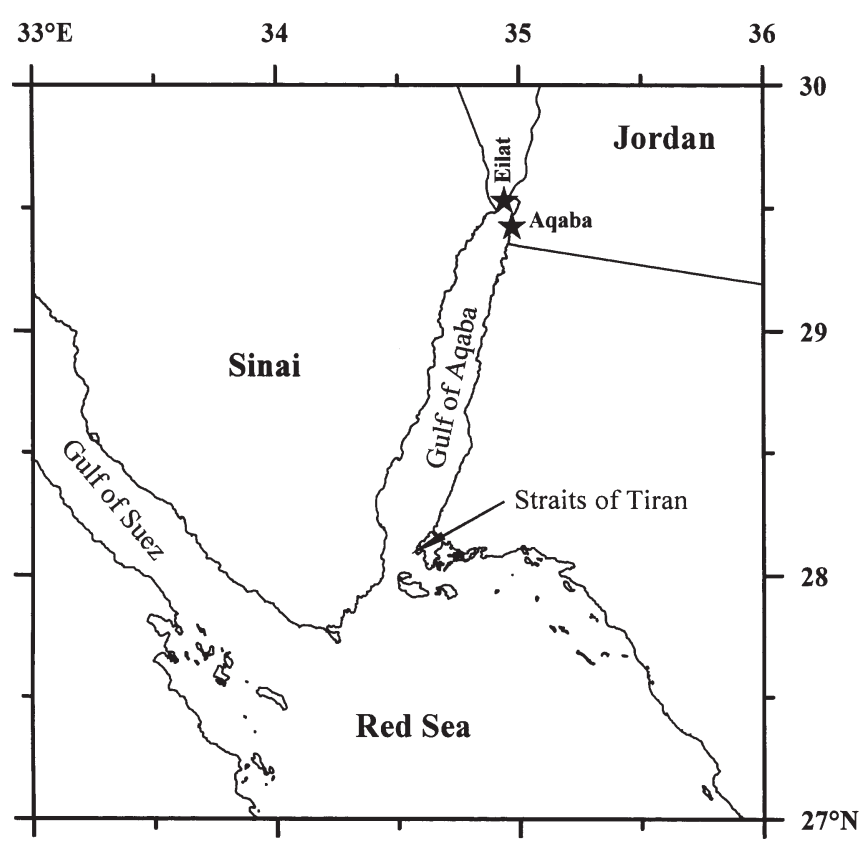

Fig. 1. Location map of the Gulf of Aqaba showing collection sites ( $\star$ ) of Porites spp. coral colonies from Aqaba and Eilat, northern Gulf of Aqaba 


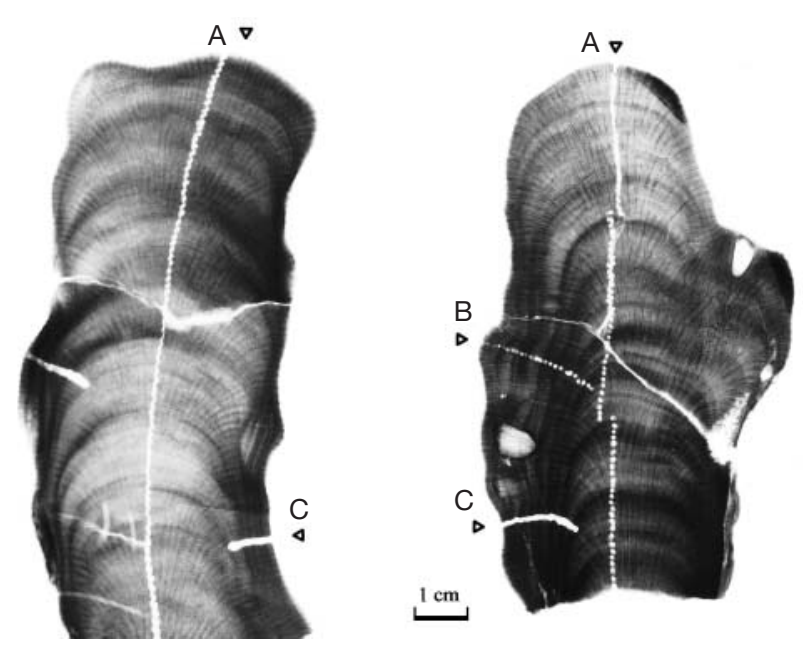

Fig. 2. Porites spp. X-radiograph-positive prints of the 2 coral slabs (Left: Aq-19; right: El-15) showing the skeletal density bands and the sampling profiles used for stable isotope analysis (Profiles A, B, and C) as indicated by the arrowheads

depending on the thickness and density of the skeleton material (Chalker \& Barnes 1990). Annual mean bulk densities were calculated from the seasonal cycles of density variations which were measured along adjacent profiles near the drilled profiles.

The monthly temperature record from Aqaba was obtained between 1997 and 2000 (R. Manasreh pers. comm.). The measurements were based on biweekly measurements in the upper $1 \mathrm{~m}$ of the water column using an OS200 CTD instrument (precision $0.001^{\circ} \mathrm{C}$ ). The measurements were performed in front of the Marine Science Station, $300 \mathrm{~m}$ away from the coral site.

Monthly measurements of SST from Eilat between 1988 and 2000 were used for comparison (A. Genin pers. comm.). The measurements were based on daily observations in the upper $20 \mathrm{~cm}$ of the water column (200 m distant from the site where the coral was collected) with a pre-calibrated mercury thermometer (precision $0.1^{\circ} \mathrm{C}$ ) fixed in a bucket.

\section{RESULTS}

\section{Seawater temperature records}

No major significant differences were observed between the SST recorded in Aqaba and Eilat. At both locations, SST show the same regular seasonal cycle and have the same seasonal amplitude $\left(5.5^{\circ} \mathrm{C}\right)$. They average $23.6^{\circ} \mathrm{C}$, with maximum temperatures of $26.4^{\circ} \mathrm{C}$ (on average) in August-September, and minimum temperatures of $20.9^{\circ} \mathrm{C}$ (on average) in February-March (Fig. 3).

\section{Salinity and $\delta^{18} \mathrm{O}$ of seawater}

Seawater $\delta^{18} \mathrm{O}\left(\delta^{18} \mathrm{O}_{\mathrm{w}}\right)$ is related to changes in salinity as a response to changes in evaporation, precipitation and mixing of waters from different sources. This relation between $\delta^{18} \mathrm{O}_{W}$ and salinity differs from ocean to ocean. In the Red Sea a change of $1 \%$ salinity causes a change of $0.29 \%$ in $\delta^{18} \mathrm{O}_{w}$ according to Craig (1966) and Andrié \& Merlivat (1989). At the northern end of the Gulf of Aqaba the salinity of the surface waters is close to $40.5 \%$, and varies by less than $0.5 \%$ throughout the year (WolfVecht et al. 1992).

Manasreh (1998) reported that average minimum salinities of $40.34 \%$ occur during winter (February) and maximum salinities of $40.56 \%$ during summer (June). These minor variations in the surface seawater salinity throughout the year are considered to have little effect on the seasonal variation of the seawater $\delta^{18} \mathrm{O}$ (Klein et al. 1992) $(0.225 \%$ salinity $=$ $0.065 \% \delta^{18} \mathrm{O}$ : Craig 1966). Therefore, the seasonal $\delta^{18} \mathrm{O}$ variation in the coral skeleton of the northern Gulf of Aqaba should be mainly controlled by SST (Heiss et al. 1999).

\section{Calibration of $\delta^{18} \mathrm{O}$ in coral skeletons}

The $\mathrm{x}$-radiograph-positive prints of the coral slabs reveal a clear and regular skeletal density-banding pattern. The alternating bands of high and low densities are annual, as confirmed by the strong seasonal cycle in $\delta^{18} \mathrm{O}$.

The comparison between local SST records and the coral $\delta^{18} \mathrm{O}$ time series is a necessary first step in the calibration of coral $\delta^{18} \mathrm{O}$ records. The oxygen isotope profiles of both corals showed well-organized cyclic variations along the axis of maximum extension rate (fast-growing tops) (Profiles Aq-19A and El-15A: Fig. 4). $\delta^{18} \mathrm{O}$ in the Aqaba coral ranged between -2.45 and $-3.55 \%$ (average $-3.10 \%$ ) and in the Eilat coral between -2.10 and $-3.28 \%$ (average $-2.79 \%$ ). Each $\delta^{18} \mathrm{O}$ profile showed strong seasonal variations with similar amplitudes. These were on average $0.80 \%$ in Aqaba and $0.83 \%$ in Eilat. Both profiles correspond remarkably well to the monthly SST measurements in Aqaba and Eilat (Fig. 5). The correlation coefficients are rather high and range between -0.84 in the Eilat coral (in the time interval 1988 to 1995 ) and -0.81 in the Aqaba coral (in the time interval 1995 to 1999). Unfortunately no instrumental temperature data were available from Aqaba during the period 1988 to 1995.

Monthly records of $\delta^{18} \mathrm{O}$ in both locations from the main growth profile (Aq-19A and AEl-15A) were cali- 


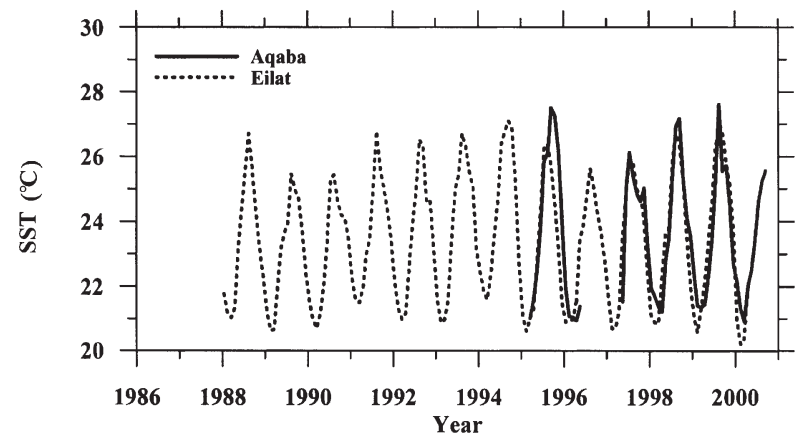

Fig. 3. Monthly recorded sea surface temperatures (SST) in Aqaba between 1997 and 2000 (R. Manasreh unpubl. data) and in Eilat between 1988 and 2000 (A. Genin unpubl. data)

brated with recorded SST, and the following equations are the results of the calculations:

$$
\begin{aligned}
& \mathrm{SST}\left({ }^{\circ} \mathrm{C}\right)=-5.93\left(\delta^{18} \mathrm{O}_{\text {coral }}\right)+4.63 \\
& \mathrm{r}=-0.81(99.5 \% \text { level }) \text { Aqaba coral } \\
& \mathrm{SST}\left({ }^{\circ} \mathrm{C}\right)=-5.75\left(\delta^{18} \mathrm{O}_{\text {coral }}\right)+7.30 \\
& \mathrm{r}=-0.84(99.5 \% \text { level }) \text { Eilat coral }
\end{aligned}
$$

The $\delta^{18} \mathrm{O} / \mathrm{SST}$ relationship from these equations varies between $0.168 \% /{ }^{\circ} \mathrm{C}$ from Aqaba and $0.174 \% /{ }^{\circ} \mathrm{C}$ from Eilat coral. The correlations from the annual averages of the $\delta^{18} \mathrm{O}$ record and the annual average SST of the 2 corals were low $(-0.25$ to -0.31$)$ despite the fact that the annual $\delta^{18} \mathrm{O}$ record follows that of the annual SST record.

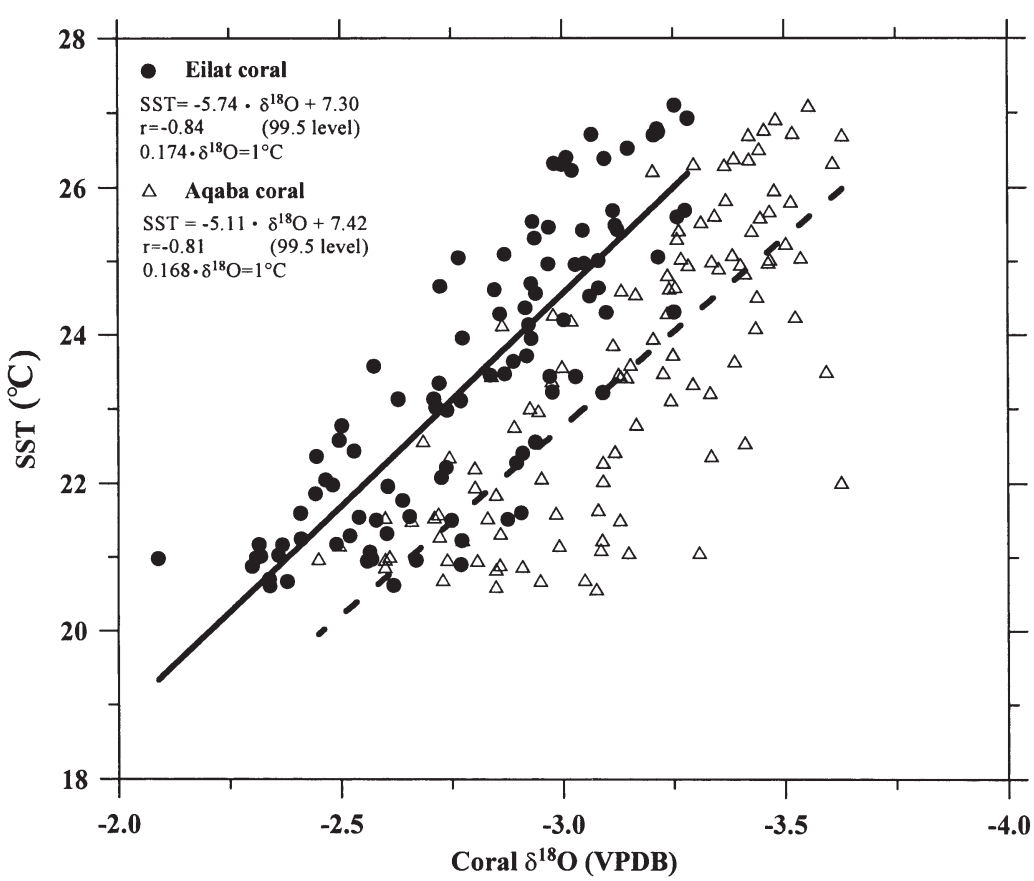

Fig. 5. Porites spp. Comparison of monthly variations in coral $\delta^{18} \mathrm{O}$ (from profiles drilled vertically along axis of maximum extension rate) with monthly recorded sea surface temperatures (SST) at Aqaba and Eilat

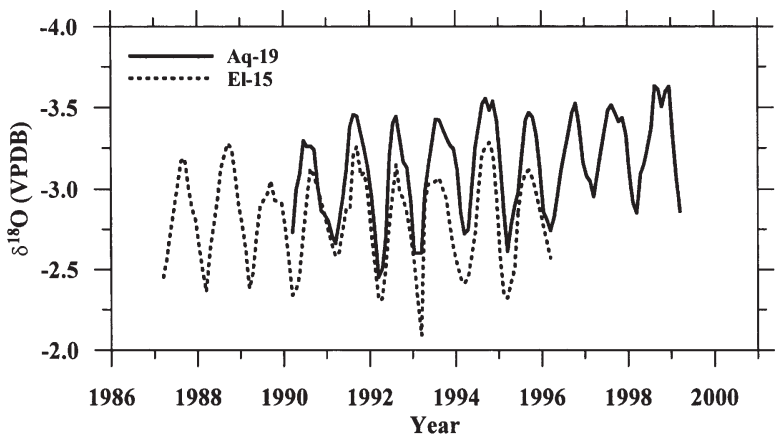

Fig. 4. Porites spp. Stable oxygen isotope profiles from samples drilled vertically along the axis of maximum extension rate of $P$. cf. lutea from Aqaba and $P$. cf. nodifera from Eilat between 1987 and 1999

\section{Extension rate and skeletal $\delta^{18} \mathrm{O}$}

Comparison of the $\delta^{18} \mathrm{O}$ records from Aqaba and Eilat (from the main profiles, Aq-19A and El-15A) for the period 1990 to 1995 shows that the Aqaba coral is several degrees more depleted in $\delta^{18} \mathrm{O}$ than the Eilat coral. The offset between the 2 colonies ranged between 0.27 and $0.36 \%$ with an average of $0.29 \%$, and appears to be constant over the length of all years covered (Fig. 4).

Annual extension rates were determined from the seasonal cycle of $\delta^{18} \mathrm{O}$ as the distance from the maximum $\delta^{18} \mathrm{O}$ value (which represents the minimum recorded temperature) in a given year to the maximum value in the following year. The Eilat coral showed lower mean annual extension rates, ranging between 7 to $13 \mathrm{~mm} \mathrm{yr}^{-1}$ (11.2 $\mathrm{mm} \mathrm{yr}^{-1}$ on average), compared to 12 to $21 \mathrm{~mm} \mathrm{yr}^{-1}$ (15.2 mm $\mathrm{yr}^{-1}$ on average) in the Aqaba coral.

We examined the relationship between annual extension rates and mean annual $\delta^{18} \mathrm{O}$ in Aqaba and Eilat corals. The $\delta^{18} \mathrm{O}$ values obtained along the slower extension rate profile (El-15A) were more enriched in $\delta^{18} \mathrm{O}$ than the faster extension rate profile (Aq-19A).

\section{Coral $\delta^{18} \mathrm{O}$ from synchronous growth profiles}

To evaluate the extension rate effect that is independent of the in situ temperature and variations in $\delta^{18} \mathrm{O}$ of the seawater, $\delta^{18} \mathrm{O}$ samples were taken from each specimen along synchronous growth profiles with different extension rates. 

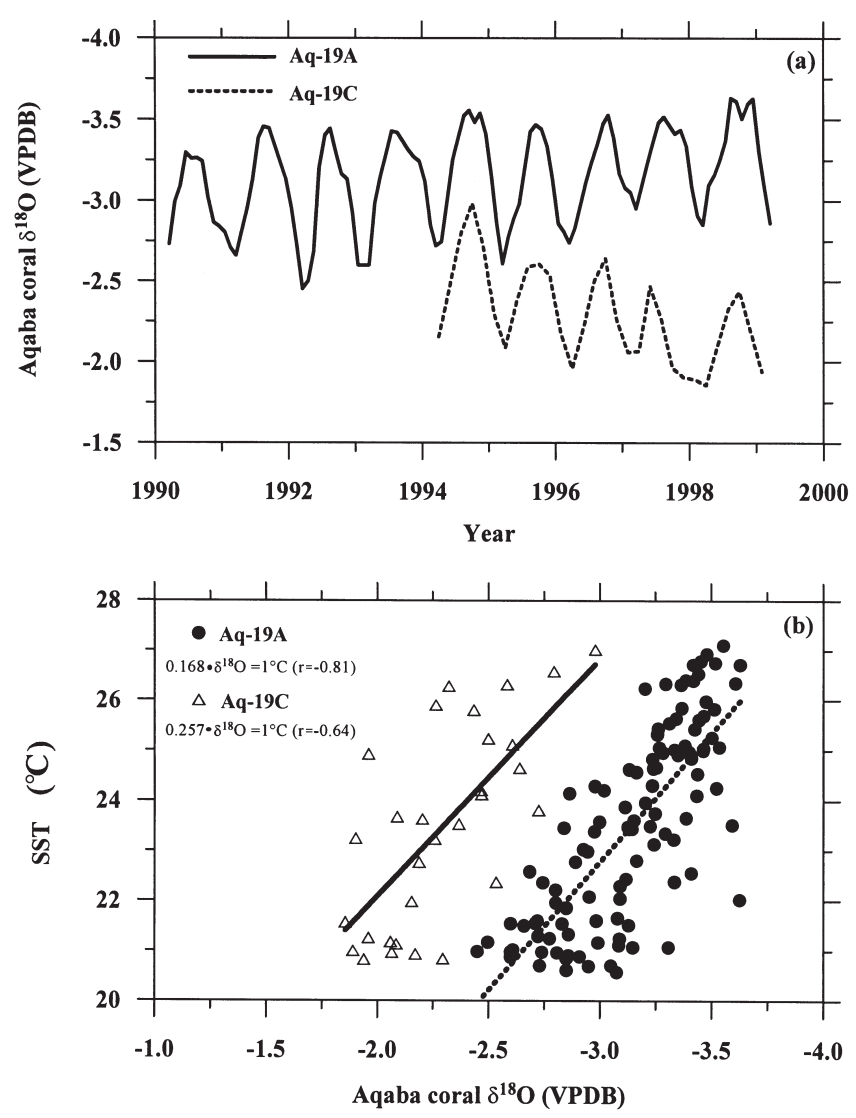

Fig. 6. Porites cf. lutea. (a) Seasonal variation in $\delta^{18} \mathrm{O}$ (VPDB) composition of Aqaba coral along 2 different profiles; (b) linear relation between $\delta^{18} \mathrm{O}$ and recorded sea surface temperatures (SST) along 2 different coral extension rate profiles (Aq-19A, $15.2 \mathrm{~mm} \mathrm{yr}^{-1}$; Aq-19C, $1.9 \mathrm{~mm} \mathrm{yr}^{-1}$ )

The bimonthly $\delta^{18} \mathrm{O}$ profile from the Aqaba coral (Aq-19C) with extension rates between 1 and $2.5 \mathrm{~mm}$ $\mathrm{yr}^{-1}$ (average $1.9 \mathrm{~mm} \mathrm{yr}^{-1}$ ) showed a seasonal amplitude of $0.73 \%$. Values ranged between -1.85 and $-2.98 \%$ (average $-2.29 \%$ ), similar to that obtained from the slowest growth profile of the Eilat coral (El$15 \mathrm{C}), 0.81 \%$ higher than the average value of the main profile from the same colony (Aq-19A) (Fig. 6a).

The bimonthly $\delta^{18} \mathrm{O}$ profiles from the slower-growing sides of the Eilat coral (El-15B and El-15C) show strong seasonal variations of 0.82 and $0.89 \%$ seasonal amplitude, similar to that obtained from the main profile from the same colony (El-15A).

The $\delta^{18} \mathrm{O}$ values from Profile El-15B ranged between -2.04 and $-3.30 \%$, with an average of $-2.68 \%$, which is $0.11 \%$ higher than that obtained from the main profile (Fig. 7a). The extension rate in this profile ranged between 2 and $5 \mathrm{~mm} \mathrm{yr}^{-1}$ (average $3.9 \mathrm{~mm} \mathrm{yr}^{-1}$ ). Also, $\delta^{18} \mathrm{O}$ values from the El-15C profile ranged between -1.75 and $-2.87 \%$ (average $-2.23 \%$ ), $0.15 \%$ higher
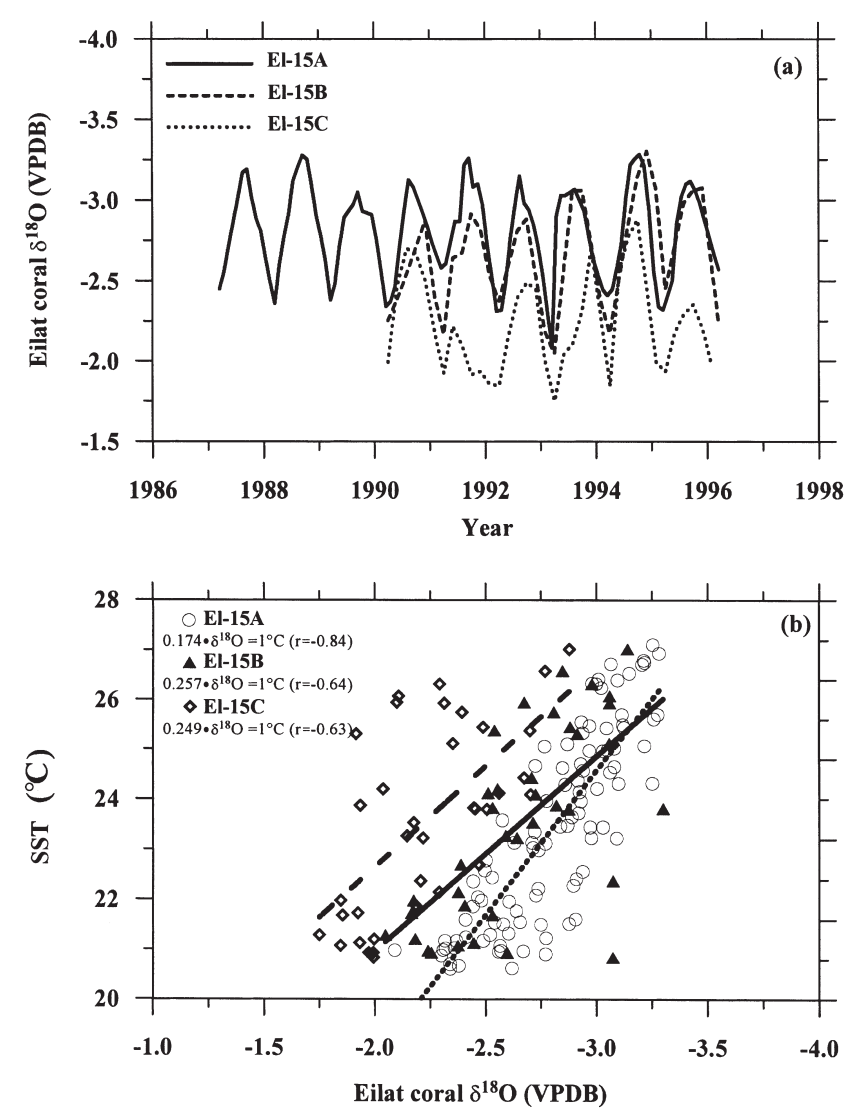

Fig. 7. Porites cf. nodifera. (a) Seasonal variation in $\delta^{18} \mathrm{O}$ (VPDB) composition of Eilat coral along 3 different profiles; (b) linear relation between $\delta^{18} \mathrm{O}$ and recorded sea surface temperatures (SST) along 3 different coral extension-rate profiles (El-15A,

$11.2 \mathrm{~mm} \mathrm{yr}^{-1}$; El-15B, $3.9 \mathrm{~mm} \mathrm{yr}^{-1}$; El-15C, $2.3 \mathrm{~mm} \mathrm{yr}^{-1}$ )

than that from El-15B (Fig. 7a). The extension rate in this profile ranged between 1.5 and $3 \mathrm{~mm} \mathrm{yr}^{-1}$ (average $2.3 \mathrm{~mm} \mathrm{yr}^{-1}$ ).

Calibration of $\delta^{18} \mathrm{O}$ from these profiles with recorded SST at bimonthly intervals, produced different $\delta^{18} \mathrm{O} /$ SST equations (Figs. $6 \mathrm{~b} \& 7 \mathrm{~b}$ ) that varied between $0.21 \%{ }^{\circ} \mathrm{C}^{-1}, 0.25 \%{ }^{\circ} \mathrm{C}^{-1}$ and $0.24 \%{ }^{\circ} \mathrm{C}^{-1}$, with correlation coefficients of $0.69,0.64$ and 0.63 from Aq-19C, El-15B, El-15C, respectively.

\section{Relation between growth variables}

Calcification rate was calculated as a product of linear extension and skeletal density (Chalker et al. 1985, Lough \& Barnes 2000). Calcification values along all profiles ranged between 2.2 and $0.157 \mathrm{~g} \mathrm{~cm}^{-2} \mathrm{yr}^{-1}$, with an average of $0.92 \mathrm{~g} \mathrm{~cm}^{-2} \mathrm{yr}^{-1}$, and decreased from the top to the sides of the colonies due to decreases in the extension rates. 

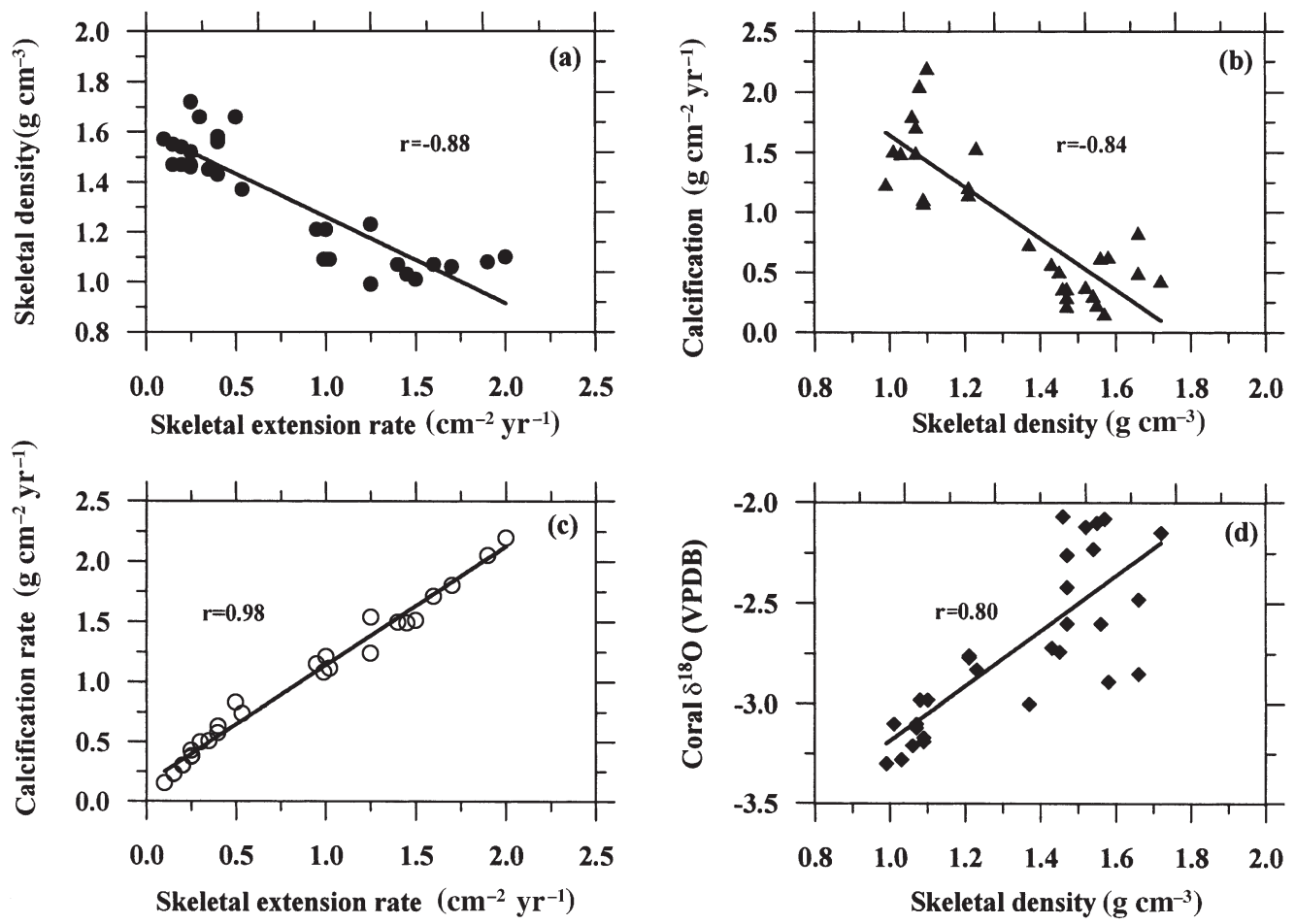

Fig. 8. Porites spp. Scatter diagram of average annual growth data for Aqaba and Eilat corals (combined data). (a) Density vs extension; (b) calcification vs extension; (c) calcification vs density; (d) density vs skeletal stable oxygen isotopes. Regression lines and correlation coefficients are shown

The relations between density, extension and calcification rate in this study (Fig. 8) are similar to the growth relations reported for other studies (Wellington \& Glynn 1983, Dodge \& Brass 1984, Scoffin et al. 1992, Lough \& Barnes 2000). Average annual extension was inversely correlated with average annual density $(\mathrm{r}=$ 0.88) and significantly correlated with average annual calcification $(\mathrm{r}=0.98)$. Average skeletal density was inversely correlated with average annual calcification $(\mathrm{r}=0.84)$ and skeletal oxygen isotope $(\mathrm{r}=0.80)$. Thus, we conclude that variations in average annual calcification were mostly caused by variations in extension rate, as found by Barnes \& Lough (1993) and Lough \& Barnes (2000).

\section{DISCUSSION}

\section{Calibration of coral $\delta^{18} \mathrm{O}$}

Our $\delta^{18} \mathrm{O} / \mathrm{SST}$ slopes from the main profiles of the Aqaba and Eilat corals $\left(0.168\right.$ and $\left.0.174 \% /{ }^{\circ} \mathrm{C}\right)$ are less than the widely accepted values of $0.22 \%$ for calcite (Epstein et al. 1953) and $0.23 \% /{ }^{\circ} \mathrm{C}$ for aragonite (Grossman \& Ku 1986), and are similar to values determined by Gagan et al. (1994) for Porites sp. at a weekly resolution from the Great Barrier Reef $\left(0.18 \% \circ /{ }^{\circ} \mathrm{C}\right)$ and by Quinn et al. (1998) for a New Caledonia Porites sp. on a monthly scale $\left(0.172 \%{ }^{\circ} \mathrm{C}\right)$.

Felis et al. (1998) and Moustafa (2000) determined a value of $0.165 \% /{ }^{\circ} \mathrm{C}$ as the most reasonable for calibration for Porites sp. from Ras Umm Sid, Red Sea (using the IGOSS temperature data set). Heiss et al. (1999) also found a value of 0.166 and $0.187 \% /{ }^{\circ} \mathrm{C}$ from monthly resolution in horizontal and vertical profiles of a $P$. lutea colony from Aqaba.

On an annual timescale, the correlation coefficient decreased to -0.25 and -0.31 . For New Caledonia corals, Quinn et al. (1998) reported that the correlation coefficient decreased from -0.87 on a seasonal timescale to -0.53 on an annual timescale. They explained this decrease as being due to salinity changes, whereby seasonal variations in salinity are small compared to those for temperature, while interannual changes in salinity are proportionally larger than their seasonal changes.

This may also be the situation in the northern Gulf of Aqaba. A regular measurement of seawater salinity over 4 yr (1997 to 2000) showed no systematic annual pattern (R. Manasreh, pers. comm. [2000]) and the average annual values differed from year to year. The interannual variations during this period were as much as $0.4 \%$, compared to $0.225 \%$ on a seasonal scale. The potential impact of $0.4 \%$ interannual salinity variation 
on $\delta^{18} \mathrm{O}$ of Red Sea water and hence on coral $\delta^{18} \mathrm{O}$ is $0.12 \%$ (after Craig 1966). This effect could explain part of the difference in the seasonal and mean annual slopes of $\delta^{18} \mathrm{O} / \mathrm{SST}$.

The measured SST in Aqaba and Eilat reveal an average annual cycle of about $5.5^{\circ} \mathrm{C}$. Using the gradient of $0.165 \% /{ }^{\circ} \mathrm{C}$ for coral $\delta^{18} \mathrm{O}$-temperature dependence from the northern Red Sea (Felis et al. 1998, Moustafa 2000), the average seasonal coral $\delta^{18} \mathrm{O}$ variation of $0.83 \%$ would reflect a temperature change of about $5.0^{\circ} \mathrm{C}$, which is about $91 \%$ of the average seasonal SST amplitude. The expected variation of $0.065 \% \delta^{18} \mathrm{O}$ in seawater (related to a $0.225 \%$ change in salinity) constitutes $7.8 \%$ of the average seasonal coral $\delta^{18} \mathrm{O}$ variation. This indicates that a large majority of the variations in coral oxygen isotope data can be explained by variations in the SST, and only a small fraction can be attributed to $\delta^{18} \mathrm{O}$ variations of surface water.

It is obvious from our results that different $\delta^{18} \mathrm{O} / \mathrm{SST}$ relations exist in different colonies and in different parts of the same colony. These variations are most probably biologically mediated, as outlined in the following subsection.

\section{Effect of extension rate on skeletal $\delta^{18} O$ composition}

Both main $\delta^{18} \mathrm{O}$ profiles for the 2 colonies (Aq-19A and El-15A) show similar amplitudes $(0.83$ and $0.80 \%$, respectively), which implies that both corals respond similarly to environmental signals. The offset between the $\delta^{18} \mathrm{O}$ profiles $\left(\sim 0.29 \%\right.$ on average, with lower $\delta^{18} \mathrm{O}$ values in the Aqaba coral) does not reflect changes in temperature and/or salinity between the 2 sites (similar physical environment) and is probably a biologically mediated signal.

Although the profiles from the coral sides (Aq-19C and El-15B, C) were sampled at lower resolution, they displayed roughly the same seasonal amplitude as the main profiles with a monthly sampling resolution. Analysis of $\delta^{18} \mathrm{O}$ along the main and synchronous growth profiles revealed different trends in the $\delta^{18} \mathrm{O}$ values (Figs. 5, 6b, 7b). These results indicate that the $\delta^{18} \mathrm{O}$ values are subject to extension and calcification rate effects, i.e. the faster-growing profile (Aq-19A) is $0.29 \%$ more depleted in $\delta^{18} \mathrm{O}$ than the slower-growing profile (El-15A). A trend of higher $\delta^{18} \mathrm{O}$ content with slower extension rate was also observed in the synchronous growth profiles of both colonies (Aq-19C, El-15B, El-15C).

The relation between coral $\delta^{18} \mathrm{O}$ and skeletal growth rate determined in this study is not linear and can be explained by a simple exponential model (Fig. 9):

$$
\begin{gathered}
\text { Coral } \delta^{18} \mathrm{O}=-3.067+\exp [1.069+(-0.744) \times \mathrm{ER}] \\
\text { Aqaba coral } \mathrm{r}=0.96 \\
\text { Coral } \delta^{18} \mathrm{O}=-2.795+\exp [1.016+(-0.757) \times \mathrm{ER}] \\
\text { Eilat coral } \mathrm{r}=0.97
\end{gathered}
$$

where ER is the coral extension rate $\left(\mathrm{mm} \mathrm{yr}^{-1}\right)$, and $\delta^{18} \mathrm{O}$ is \% VPDB.

Coral $\delta^{18} \mathrm{O}$ data from Aqaba and Eilat and from the same genus (Porites) with different extension ratesCoral S4 $\left(6.8 \mathrm{~mm} \mathrm{yr}^{-1}\right)$, Coral MB30 (3.3 $\left.\mathrm{mm} \mathrm{yr}^{-1}\right)$, Coral IS50 $\left(2.0 \mathrm{~mm} \mathrm{yr}^{-1}\right)$ and Coral S6 (14.8 $\left.\mathrm{mm} \mathrm{yr}^{-1}\right)$ (Klein et al. 1993, J. Pätzold \& R. Klein unpubl. data), Aq-193 $\left(20 \mathrm{~mm} \mathrm{yr}^{-1}\right)$, Coral Aq-292 (5.3 $\left.\mathrm{mm} \mathrm{yr}^{-1}\right)$ and Coral Aq-424 (3.5 $\mathrm{mm} \mathrm{yr}^{-1}$ ) (Al-Rousan unpubl. data) are also plotted in Fig. 9. The data fit the curve and support the reliability of the exponential model.

The inverse relationship between $\delta^{18} \mathrm{O}$ and extension rate revealed by this model applies to growth rates of 1 to $5 \mathrm{~mm} \mathrm{yr}^{-1}$ (Profiles Aq-19C, Aq-292, Aq-424, El15B, El-15C, MB30, and IS50). For more rapidly growing corals and portions of corals (as in Profiles Aq-19A, Aq-193, El-15A, S4 and S6: Fig. 9), the relation is constant, and the extension rate does not appear to have a significant effect on coral $\delta^{18} \mathrm{O}$.

These results are similar to those of McConnaughey (1989), who found an inverse relationship for Galápa-
Fig. 9. Porites spp. Exponential relationship between skeletal $\delta^{18} \mathrm{O}$ and skeletal extension rate of colonies sampled along vertical (main axis) and horizontal (coral sides) profiles of corals collected from the northern Gulf of Aqaba, Red Sea. Data for Corals IS51, MB30 and S4 are from Klein et al. (1993), data for S6 from J. Pätzold and R. Klein (unpubl. data), and for Aq-193, Aq-292 and Aq-424 from S. Al-Rousan (unpubl. data)

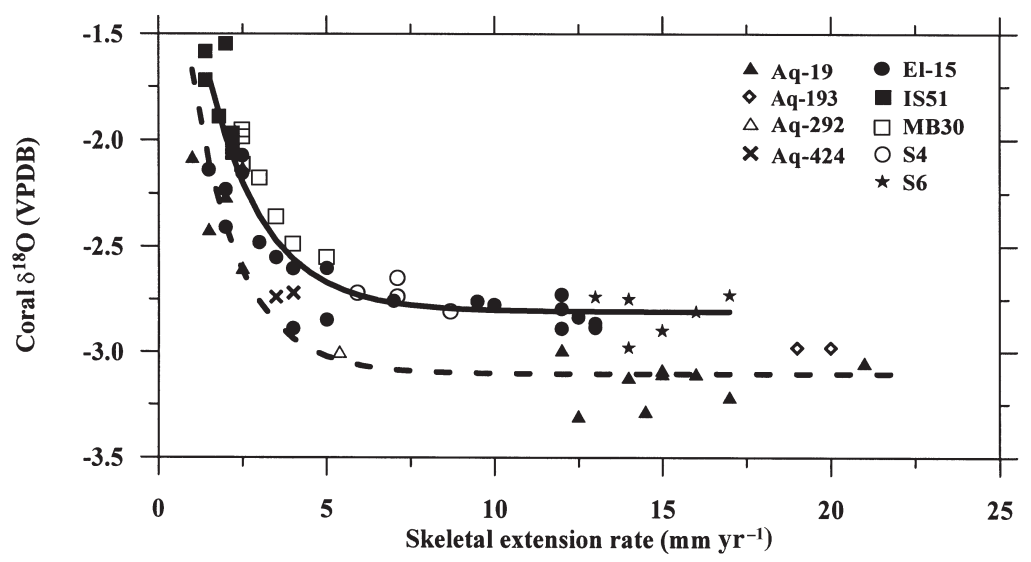


gos Pavona clavus corals that grew at rates of $<5 \mathrm{~mm}$ $\mathrm{yr}^{-1}$, and extension rate did not appear to have any significant effect on $\delta^{18} \mathrm{O}$ composition at growth rates of $>5 \mathrm{~mm} \mathrm{yr}^{-1}$. Quinn et al. (1998) also found a negative correlation in New Caledonia corals, and Allison et al. (1996) in corals from Phuket, South Thailand-but at all extension rates. Higher $\delta^{18} \mathrm{O}$ and $\mathrm{Sr} / \mathrm{Ca}$ values in slower growing transects were reported by de Villiers et al. (1995) for Pavona clavus from Galápagos. In contrast, Leder et al. (1996) found that the $\delta^{18} \mathrm{O}$ content of rapidly growing portions $\left(8 \mathrm{~mm} \mathrm{yr}^{-1}\right.$ ) of a colony was 0.1 to $0.2 \%$ higher than that of the slowest growing portions $\left(1.1 \mathrm{~mm} \mathrm{yr}^{-1}\right)$, and explained this as a result of reduced sampling resolution in slower growing portions of the coral and not a result of variable kinetic effects.

We conclude that growth rate has an important effect on the isotopic composition of coral skeletons. Our results support the conclusion drawn by McConnaughey (1989) that the depletion of $\delta^{18} \mathrm{O}$ is characteristic for kinetic fractionation associated with rapid calcification, and that isotope disequilibria tend to be fairly consistent in rapidly growing parts of photosynthetic corals. For this reason, we suggest that $\delta^{18} \mathrm{O}$ should be measured in fast-growing portions where the extent of isotopic disequilibria is largest, since isotopic disequilibria are too variable in slow-growing parts.

\section{Calcification rate and species-specific effects}

As shown in Fig. 9, a $\delta^{18} \mathrm{O}$ offset between Aqaba and Eilat colonies does exist. We calculated the calcification rate along the drilled profiles. Due to the high correlation between extension and calcification rate (Fig. 8c) the relation between calcification and $\delta^{18} \mathrm{O}$

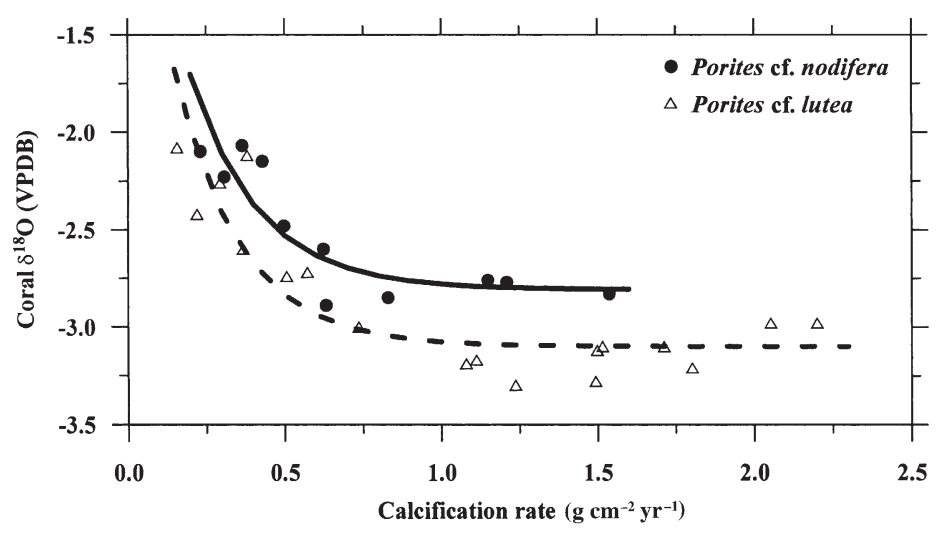

Fig. 10. Porites spp. Exponential relationship between skeletal $\delta^{18} \mathrm{O}$ and skeletal calcification rate for 2 species collected from the northern Gulf of Aqaba, Red Sea failed to explain the offset between the main $\delta^{18} \mathrm{O}$ profiles for the 2 colonies. A similar exponential equation was produced (Fig. 10). We found that high extension profiles revealing low skeletal densities (Aq-19A) were depleted in $\delta^{18} \mathrm{O}$ compared to low extension profiles showing high densities (El-15A) which may have had the similar calcification rate.

The offset between $\delta^{18} \mathrm{O}$ profiles cannot always be explained as a function of extension and/or calcification rate. For this reason, both corals were taxonomically identified. Aq-19, Aq-193, Aq-292 and Aq-424 (which are depleted in $\delta^{18} \mathrm{O}$ by $\sim 0.29 \%$ compared to El$15)$ are Porites cf. lutea, while El-15 is P. cf. nodifera. Wellington et al. (1996) found that certain species are enriched or depleted in $\delta^{18} \mathrm{O}$ relative to other species of the same genus living under the same environmental conditions, whereas Grottoli (1999) found for Hawaii corals that $\delta^{18} \mathrm{O}$ varies among species. Species-specific offsets in $\delta^{18} \mathrm{O}$ have been also reported by Weil et al. (1981). The $\delta^{18} \mathrm{O}$ offset between coral species may reflect some genetic differences which alter the extent of isotopic disequilibria (Allison et al. 1996).

The results of this study show that the linear extension rate and species variation should be considered when interpreting coral $\delta^{18} \mathrm{O}$ data for paleoclimatic studies. Further studies are also needed to study the variation of $\delta^{18} \mathrm{O}$ of other Porites species.

\section{CONCLUSIONS}

The high correlation between coral $\delta^{18} \mathrm{O}$ and recorded SST (-0.84) in both Aqaba and Eilat in the northern Red Sea suggests that the great majority of the seasonal variations in coral oxygen isotopes can be explained by the SST variations, and only a small fraction can be attributed to $\delta^{18} \mathrm{O}$ variations in the surface water. These results support the concept of using northern Red Sea corals as recorders of variability in SST. Interannual salinity variations in the Gulf of Aqaba (as recorded in recent studies) seem to be responsible for decreasing the correlation between coral $\delta^{18} \mathrm{O}$ and SST on the annual timescale.

Different $\delta^{18} \mathrm{O} / \mathrm{SST}$ relations from 2 different colonies and also from the same colonies were obtained, indicating that $\delta^{18} \mathrm{O}$ of coral skeletons is subject to an extension rate effect. Significant $\delta^{18} \mathrm{O}$ depletion occurs at high extension rates, and higher values at low extension rates. The relation between $\delta^{18} \mathrm{O}$ and extension rate is not linear, and can be explained by a simple exponential model in which the inverse function extends over extension rates of 1 to $5 \mathrm{~mm} \mathrm{yr}^{-1}$. For more rapidly growing corals and portions 
of coral colonies, the relation is constant, and the extension rate did not appear to have any significant effect on coral $\delta^{18} \mathrm{O}$. The offset in $\delta^{18} \mathrm{O}$ profiles cannot always be explained as a function of extension and/or calcification rate, and may result from interspecific differences between corals.

We suggest that $\delta^{18} \mathrm{O}$ values from Porites spp. corals should be measured from fast-growing corals or portions of the colonies (growth rate of $>5 \mathrm{~mm} \mathrm{yr}^{-1}$ ), in which the isotopic disequilibrium is fairly constant. Skeletal extension rate and coral species should be considered when interpreting and comparing coral paleoclimatic data from various coral species with different extension rates.

Acknowledgements. We wish to thank Y. Loya for coral sample collection at Eilat. Special thanks are also due to R. Manasreh and A. Genin for providing temperature records from Aqaba and Eilat. All isotopic measurements were carried out at Bremen University. We are grateful to M. Segl for stable isotope analysis and U. Röhl for introduction to the Multi Sensor Core Logger. This work is part of the Red Sea Programme (RSP, II), funded by the German Federal Ministry of Education, Science, Research, and Technology (BMBF).

\section{LITERATURE CITED}

Allison NT, Tudhope AW, Fallick AE (1996) Factors influencing the stable carbon and oxygen isotopic composition of Porites lutea coral skeletons from Phuket, south Thailand. Coral Reefs 15:43-57

Andrié C, Merlivat L (1989) Contribution des données isotopique de deutérium, oxygène-18, hélium-3 et tritium, à l'étude de la circulation de la Mer Rouge. Oceanol Acta 12:165-174

Barnes DJ, Lough JM (1993) On the nature and causes of density banding in massive coral skeletons. J Exp Mar Biol Ecol 167:91-108

Chalker BE, Barnes DJ (1990) Gamma densitometry for the measurement of coral skeleton density. Coral Reefs 9: $11-23$

Chalker BE, Barnes DJ, Isdale PJ (1985) Calibration of X-ray densitometry for measurement of coral skeletal density. Coral Reefs 4:95-100

Charles CD, Hunter DE, Fairbanks RG (1997) Interaction between the ENSO and the Asian monsoon in a coral record of tropical climate. Science 277:925-928

Cohen AL, Hart SR (1997) The effect of colony topography on climate signals in coral skeleton. Geochim Cosmochim Acta 61:3905-3912

Craig H (1966) Isotopic composition and origin of the Red Sea and Salton Sea geothermal brines. Science 154:1544-1548

de Villiers S, Nelson BK, Chivas AR (1995) Biological controls on coral $\mathrm{Sr} / \mathrm{Ca}$ and $\delta^{18} \mathrm{O}$ reconstructions of sea surface temperatures. Science 269:1247-1249

Dodge RE, Brass GW (1984) Skeletal extension, density and calcification of the reef coral, Montastrea annularis: St. Croix, U.S. Virgin Islands. Bull Mar Sci 34:288-307

Epstein S, Buchsbaum R, Lowenstam HA, Urey HC (1953) Revised carbonate-water isotopic temperature scale. Geol Soc Am Bull 64:1315-1322

Felis T, Pätzold J, Wefer G, Fine M, Loya Y, Nawar AH (1998)
First results of a coral-based history of recent climate in the northern Red Sea. Zentbl Geol Paläont Teil I :197-209

Gagan MK, Chivas AR, Isdale PJ (1994) High-resolution isotopic records from corals using ocean temperature and mass-spawning chronometers. Earth Planet Sci Lett 121: $249-258$

Gagan MK, Ayliffe LK, Beck JW, Cole JE, Druffel ERM, Dunbar RB, Schrag DB (2000) New views of tropical paleoclimates from corals. Quat Sci Rev 19:45-64

Goreau TJ (1977) Coral skeletal chemistry: physiological and environmental regulation of stable isotopes and trace metals in Montastrea annularis. Proc R Soc Lond Ser B 196:291-315

Grossman EL, Ku TL (1986) Oxygen and carbon isotope fractionation in biogenic aragonite: temperature effects. Chem Geol (Isotope Geosci Sect) 59:59-74

Grottoli AG (1999) Variability of stable isotope and maximum linear extension in reef-coral skeletons at Kaneohe Bay, Hawaii. Mar Biol 135:437-449

Heiss GA, Dullo WC, Joachimski M, Reijmer J, Schuhmacher $H$ (1999) Increased seasonality in the Gulf of Aqaba, Red Sea recorded in the oxygen isotope record of a Porites lutea coral. Senckenb Marit 30:17-26

Klein R, Pätzold J, Wefer G, Loya Y (1992) Seasonal variations in the stable isotopic composition and the skeletal density pattern of the coral Porites lobata (Gulf of Eilat, Red Sea). Mar Biol 112:259-263

Klein R, Pätzold J, Wefer G, Loya Y (1993) Depth-related timing of density band formation in Porites spp. corals from the Red Sea inferred from X-ray chronology and stable isotope composition. Mar Ecol Prog Ser 97:99-104

Knutson DW, Buddemeier RW, Smith SV (1972) Coral chronometers: seasonal growth bands in reef corals. Science 177: $270-272$

Land LS, Lang JC, Barnes DJ (1975) Extension rate: a primary control on the isotopic composition of West Indian (Jamaican) scleractinian reef coral skeletons. Mar Biol 33: 221-233

Leder JJ, Swart PK, Szmant AM, Dodge RE (1996) The origin of variations in the isotopic record of scleractinian corals: I. Oxygen. Geochim Cosmochim Acta 60:2857-2870

Lough JM, Barnes DJ (2000) Environmental controls on growth of the massive coral Porites. J Exp Mar Biol Ecol 245:225-243

Manasreh RS (1998) Water circulation in the Gulf of Aqaba, Red Sea. MSc thesis, Yarmouk University, Irbid, Jordan

McConnaughey $\mathrm{T}(1989){ }^{13} \mathrm{C}$ and ${ }^{18} \mathrm{O}$ isotopic disequilibrium in biological carbonates. I. Patterns. Geochim Cosmochim Acta 53:151-162

Moustafa YA (2000) Paleoclimatic reconstructions of the northern Red Sea during the Holocene inferred from stable isotope records of modern and fossil corals and molluscs. Berichte Fachbereich Geowissenschaften Universität Bremen No. 153. Universität Bremen

Paillard D, Labeyrie L, Yiou P (1996) Macintosh Program Performs time-series analysis. EOS Trans Am Geophys Un $77(39): 379$

Pätzold J (1986) Temperature and $\mathrm{CO}_{2}$ changes in tropical surface waters of the Philippines during the past 120 years: record in the stable isotopes of hermatypic corals; Berichte, Geologisches Paläontologisches Institut Universität Kiel, No. 12, Kiel

Quinn TM, Crowely TJ, Taylor FW, Henin C, Joannot P, Join Y (1998) A multicentury stable isotope record from a New Caledonia coral: interannual and decadal sea surface temperature variability in the southwest Pacific since 1657 A.D. Paleoceanography 13:412-426 
Reiss Z, Hottinger L (1984) The Gulf of Aqaba: ecological micropaleontology. Springer-Verlag, Berlin

Scoffin TP, Tudhope AW, Brown BE, Chansang H, Cheeney RF (1992) Patterns and possible environmental controls of skeletogenesis of Porites lutea, south Thailand. Coral Reefs 11:1-11

Wefer G, Berger WH (1991) Isotope paleontology: growth and composition of extant calcareous species. Mar Geol 100: 207-248

Weil S, Buddemeier R, Smith S, Kroopnick P (1981) The stable isotopic composition of coral skeletons: control by

Editorial responsibility: Gotthilf Hempel,

Bremen, Germany environmental variables. Geochim Cosmochim Acta 45: $1174-1153$

Wellington G, Glynn P (1983) Environmental influences on skeletal banding in eastern Pacific (Panama) corals. Coral Reefs 1:215-222

Wellington GM, Dunbar RB, Merlen G (1996) Calibration of stable isotope signature in Galápagos corals. Paleoceanography 11:467-480

Wolf-Vecht A, Paldor N, Brenner S (1992) Hydrographic indicators of advection/convection effects in the Gulf of Eilat. Deep-Sea Res 39:1393-1401

Submitted: May 3, 2001; Accepted: January 31, 2002

Proofs received from author(s): August 9, 2002 